\title{
Evaluation of Advance Generation Populations of Cotton (Gossypium hirsutum L.) for High Ginning Out Turn Percent and Yield
}

\author{
S.L. Ahuja ${ }^{*}$, D. Monga, Rishi Kumar and S.K. Sain
}

Indian Council for Agricultural Research-Central Institute for Cotton Research Regional Station, Sirsa, Haryana-125055, India

*Corresponding author

\section{A B S T R A C T}

\begin{tabular}{|l|}
\hline K e y w o r d s \\
$\begin{array}{l}\text { Advance generation } \\
\text { population, Gossypium } \\
\text { hirsutum, Ginning out } \\
\text { turn percent, Lint yield } \\
\mathrm{kg} / \text { hectare }\end{array}$ \\
\hline Article Info \\
\hline $\begin{array}{l}\text { Accepted: } \\
\text { 20 August } 2018 \\
\text { Available Online: } \\
\text { 10 September } 2018\end{array}$ \\
\hline
\end{tabular}

Key words

population hirsutum, Ginning out

\section{Introduction}

Historically, cotton breeders have focused on seed cotton yield, quality, maturity and host plant resistant traits. Advances in breeding for increased lint yield have slowed down perhaps because of its relatively low heritability and high environmental interaction. Approaches to enhance lint yield by increasing ginning out turn percent (GOT\%) (presently around 35\% in India) should help breeder to break the productivity barriers in response to global competition.

Number of seeds per boll, ginning out turn per cent and lint index exhibit high narrow sense heritability (h2 n.s.) due to the presence of additive gene action, whereas seed weight per boll, seed index and lint yield possess low heritability. The genetic analysis suggested that number of seeds per boll, and lint index could be upgraded through full-or half-sib family, pedigree and progeny selection, ginning out turn per cent while exploitation of hybrid vigour would probably be the way to achieve the genetic progress in seed weight per boll, seed index and lint yield.

Workers who achieved hybrid vigour for ginning out turn per cent (Ansari et al., 1989, Yuan et al., 2001, 2002; Wei et al., 2002 Panhwar et al., 2008; Iqbal, 2003). 
Delinking of negatively associated desirable (high yield) and undesirable (poor fibre quality) traits had been a breeding challenge in cotton. Joshi and his students could address this problem by indigenous breeding/selection strategies. Cotton varieties known as JK series ( $\mathrm{J}$ stands for Joshi and $\mathrm{K}$ for Kadappa, student of Joshi and well-known cotton breeder in Karnataka) combining high ginning outturn and high fibre strength and fineness in highyield backgrounds are the outcome of this effort. It was his belief that yield stagnation at low levels for long in cotton could be breached by exploitation of hybrid vigour (Siddiq, 2010).

The present study has helped in developing material with broad genetic base, superior donor lines and development of parents with high productivity. Taking into average seed cotton yield as $25 \mathrm{q} / \mathrm{ha}$ every $1 \%$ increase in ginning out turn per cent will result $25 \mathrm{Kg}$ lint yield/ha increase and targeted $5-7 \%$ shall result 125 to $175 \mathrm{Kg} / \mathrm{ha}$ lint yield increase in addition to enhancement in seed cotton yield.

\section{Materials and Methods}

\section{Genetic materials}

Eleven agronomical high yielding varieties (H1098, F 1861, F1378 9C, LH2107, LH-108, F2164, F846, LH1134, CSH3129, H 1226 and RS875) of India were used as female parent, IC 359508, IC 358382, IC 357203, IC 357671, IC 356665, IC 358479, SA1237, IC 357726, EC356785, EC359059, EC358002, SA668 and SA524 (IC=Indigenous collections and others were $\mathrm{EC}=$ exotic collections) high ginning out turn $(\mathrm{GOT} \%) \geq 40$ male parents were crossed in 2011-12 Kharif crop season (Table 1) to identify high yielding $F_{1}$ hybrids possessing ginning out turn (GOT\%) $\geq 40$ in 2012-13 crop season (Table 2). In the crop season 2013-14, higher yielding (in comparison to agronomically superior parent) approximately 200 plants of two crosses (RS875xSA-524, F-1861xSA-668) $\mathrm{F}_{2} \mathrm{~S}$ (selfed) and out of 16 crosses of each variety with GOT\% hybrid vigour $>=40 \%$ were selected raised in the next season. In the crop season 2014-15, 200 plants in the $F_{3}$ generation were raised and selfed seeds of these two selected crosses were ginned and higher yielding plants with GOT\% >or $=40 \%$. In 2015-16 and 201617 crop season higher yielding $F_{4}$ plants and F5 plants (about 200) of two crosses with GOT $\%>=40 \%$ were raised and selfed and plants with GOT\% $>40 \%$ were selected. Nineteen $\mathrm{F}_{5}$ populations selected from these two crosses involving G.hirsutum cotton varieties R875 and F-861 with South American germplasm lines SA524 and SA668 were evaluated in randomized block design with three replications in the Kharif season of 2016-17 along two check varieties H1226 and F1861 at ICAR-Central Institute for Cotton Research Regional Station, Sirsa, Haryana125055 (India)

\section{Details of experiment}

The field experiment was started in 2016-17 cropping season with the dated of sowing was 28 April 2016 with the spacing of $67.5 \mathrm{x}$ $30 \mathrm{~cm}$. Number of $F_{5}$ populations were 19 (of Crosses of RS-875xSA-524 and F1861xSA668). For each population three replications were maintained in three rows in each replication. The single plot area per replication was 10.33sqm. The two checks (H1226 and F1861) were also sown for control. The agronomic practices were implemented as per the recommendations. The final picking was done on 11 November 2016.

\section{Experimentation and data recording}

Recommended agronomic practices were followed to raise the crop. The data were recorded on 10 random plants for the traits number of bolls /plant, monopodial 
branches/plant, sympodial branches/plant, plant height $(\mathrm{cm})$, boll weight $(\mathrm{g})$ and seed cotton yield of three rows in each replication of each of the advance generation population and the two checks. Ginning out turn percent was estimated by weighing the percent amount of lint obtained from $100 \mathrm{gm}$ of seed cotton. Lint yield was calculated as a multiple of seed cotton yield $\mathrm{kg} /$ hectare and ginning outturn per cent and division by 100 .

\section{Disease and insect pest data recording}

Number of jassids, thrips, whitefly and leaf hoppers were counted in the first week of September on three leaves (one each of upper, middle and lower portion of the plant) of three random plants in each replication and were averaged for each replication. For cotton leaf curl diseases (CLCuD) symptom was graded (at 120 days, the total plants as on that date, including the previous ones were also graded) according to standard 0-6 rating scale for CLCuD (Monga, 2014). PDI (Per cent disease index) for leaf curl disease CLCuD was calculated as (overall mean grades of the three replications infected plants with the disease/ 6) x100.

\section{Fibre quality data}

Fibre quality traits $2.5 \%$ span length $(\mathrm{mm})$, fibre strength gram/tex, microenare value and uniformity ratio were estimated through HVI (high volume instrument) by Central Institute for Research on Cotton Technology unit at CICR, Regional Station, Sirsa, Haryana, India

\section{Data analysis}

The analysis of variance was done following the method of Panse and Sukhatme (1978). In order to compare significance of particular variety from the other critical difference was calculated following Singh and Chaudhary (1985).

\section{Results and Discussion}

\section{Analysis of variance}

The analysis of variance revealed significant differences among the $19 \mathrm{~F}_{5}$ individual plant progenies of the two crosses viz; RS875xSA524 and F1861xSA668) and two check varieties H1226 and F1861.for all the eight traits viz., seed cotton yield $\mathrm{kg} / \mathrm{hectare}$, lint yield $\mathrm{kg} /$ hectare number of bolls per/plant, boll weight $(\mathrm{g})$, number of monopodia branches/plant, number of sympodia/plant, plant height $(\mathrm{cm})$ including ginning out turn percent. Information is given in Table 4, 5 and 6.

\section{Results of 19 advance generation $\mathbf{F}_{5}$ populations}

In the 19 advance generation populations of the two crosses (RS875xSA524 and F1861xSA668) under evaluation seed cotton yield $\mathrm{kg} /$ hectare ranged from 897.70 to 2304.52, lint yield $\mathrm{kg} /$ hectare 364 to 935.60 , number of bolls per/plant from 18.5 to29.3, boll weight (g) 2.57 to 3.63 , ginning out turn percent from 32.73 to 40.60 , plant height $(\mathrm{cm})$ 85.23 to 136.33 , number of monopodia branches/plant 0.0 to1.6 and number of sympodia branches/plant from 11.73 to18.73. For fibre property traits viz. $2.5 \%$ span length (mm) from 24.4 to 27.9 , fibre strength ( $\mathrm{g} /$ tex) from 24.1 to 26.6 , micronare value from 4.2 to 5.5. Respective average values in the material evaluated were seed cotton yield $\mathrm{kg} / \mathrm{hectare}$ (1441I, lint yield kg/hectare (548.72), number of bolls per/plant (24.13), boll weight (g) (2.93), ginning out turn percent (38.25), plant height $(\mathrm{cm})$ (110.40), number of monopodia branches/plant (0.67) and number of sympodia branches (15.90). There were two check varieties viz., H-122 6 (from Haryana State and F-1861 (from Punjab State). Seed cotton yield $\mathrm{kg} /$ hectare of these varieties was 1712.37 \pm 291.29 and $1751.09 \pm 291.29$ The later 
variety check had significantly higher seed

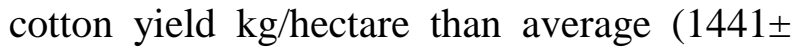
291.29) suggesting that some of the 19 advance generation populations of the two crosses had significantly lesser seed cotton yield $\mathrm{kg} /$ hectare. The two check varieties had lint yield $\mathrm{kg} /$ hectare $592.49 \pm 80.69$ and 593.40 \pm 80.69 and the average lint yield $\mathrm{kg} /$ hectare was $548.72 \pm 80.69$ which was statically at par with both of the check varieties. Ginning out turn percent of the two check varieties was $34.50 \pm 1.01$ and $34.0 \pm 1.01$ and was significantly lower than overall average $38.25 \pm 1.01$. Information on this trait therefore, also suggested that ginning out turn percent of 19 advance generation populations of the two crosses was significantly higher than the two check varieties. The two check varieties $\mathrm{H}$ 1226 and F-1861 had boll weight (g) of $2.80 \pm 025$ and $2.90 \pm 025$ and overall average boll weight of the evaluated material was $2.93 \pm 025$.

This showed that advance generation material evaluated possessed statically at par with the boll weight (g) of both of the checks. The two check varieties possessed number of bolls per/plant as $19.10 \pm 3.93$ and $17.67 \pm 3.93$ and the overall average of the material evaluated was 24.13 \pm 3.93 . Observations recorded on number of bolls per/plant revealed that the 19 advance generation populations of the two crosses had significantly higher number of bolls per plant than the two check varieties. Plant height $(\mathrm{cm})$ of the two check varieties was $136.33 \pm 19.43$ and $133.0 \pm 19.43$ and overall average of 19 advance generation populations of the two crosses and two checks was $110.42 \pm 19.43$. Number of monopodia branches per plant possessed by the check variety $\mathrm{H}-1226$ and $\mathrm{F}-1861$ were $1.2 \pm 0.64$ and $1.17 \pm 0.64$ respectively, whereas overall average was $0.67 \pm 0.64$. Number of sympod branches/plant of the two check varieties was $12.33 \pm 2.13$ and $12.0 \pm 2.13$ and the average was $15.91 \pm 2.13$ revealing that 19 advance generation populations of the two crosses had significantly higher fruit bearing branches than the two check varieties. This information further supported the observation that the 19 advance generation populations of the two crosses had significantly higher number of bolls per/plant than the two check varieties. Information on fibre traits has been given in Table 5. 2.5\% span length $(\mathrm{mm})$ of the check varieties $\mathrm{H}-1226$ and $\mathrm{F}-1861$ was; $27.7 \pm 0.40$ and $27.9 \pm 0.40$, respectively and average was $25.5 \pm 0.40$ which was significantly lower than both of the check varieties. However, in respect of fibre strength values were at par with check variety H-1226 only (Table 5).

\section{Results of top 5 advance generation $F_{5}$ populations}

Among $19 \mathrm{~F}_{5}$ individual plant progenies of the two crosses viz; RS-875xSA-524 and F1861xSA-668 top five advance generation populations in respect of seed cotton yield $\mathrm{kg} /$ hectare were; RS875xSA524 P12, F1861xSA668 P15, RS875xSA524 P4, F1861xSA668 P57 and F1861xSA668 P6 and their respective seed cotton yield in $\mathrm{kg} / \mathrm{hectare}$ were; 2304.52, 2202.85, 2198.01, 1931.73 and 1849.42. First three advance generation populations RS875xSA524 P12, F1861xSA668 P15, RS875xSA524 P4, had significantly higher seed cotton yield in comparison to both the check varieties H1226 $(1717.37 \pm 292.3)$ and (F18611751.09 \pm 292.3$)$ and last two generation advance populations F1861xSA668 P57 and F1861xSA668 were spastically at par with the two check varieties.

Lint yield $\mathrm{kg} / \mathrm{hectare}$ of the top five advance generation populations was; 935.60, 848.00, 857.22, 772.4 and 730.5. All the top five advance generation populations had significantly higher lint yield $\mathrm{kg} / \mathrm{hectare}$ in comparison to both the check varieties; $592.49 \pm 80.69$ and 593.40 \pm 80.69 . 
Table.1 F1's attempted between 11 agronomically superior varieties and high GOT germplasm lines (Male and Female parents of crosses attempted in 2012-13)

\begin{tabular}{|c|c|c|c|}
\hline Sr. No. & Female Parents & Sr. No. & $\begin{array}{c}\text { Male Parents (High } \\
\text { GOT\% 37 to 41\%) }\end{array}$ \\
\hline $\mathbf{1}$ & H1098 & 1 & I-359508 \\
\hline $\mathbf{2}$ & F1861 & 2 & IC357333 \\
\hline $\mathbf{3}$ & F-1378 & 3 & IC358382 \\
\hline $\mathbf{4}$ & LH2107 & 4 & IC357203 \\
\hline $\mathbf{5}$ & LH2108 & 5 & IC357631 \\
\hline $\mathbf{6}$ & F2164 & 6 & IC356665 \\
\hline $\mathbf{7}$ & F846 & 7 & IC358479 \\
\hline $\mathbf{8}$ & LH1134 & 8 & SA1237 \\
\hline $\mathbf{9}$ & CSH3129 & 9 & IC357726 \\
\hline $\mathbf{1 0}$ & H1226 & 10 & EC356785 \\
\hline $\mathbf{1 1}$ & RS875 & 11 & EC359059 \\
\hline & & 12 & EC358002 \\
\hline & & 13 & EC357032 \\
\hline & & 14 & EC359044 \\
\hline
\end{tabular}

Table.2 Performance of $176 \mathrm{~F}_{1}$ 's of 11 Agronomically superior females and high GOT\% 16 germplasm lines

\begin{tabular}{|c|c|c|c|c|c|c|c|}
\hline \multicolumn{2}{|c|}{ No. of parents } & \multirow[t]{2}{*}{$\begin{array}{l}\text { No. of } \\
\text { crosses }\end{array}$} & \multicolumn{2}{|c|}{$\begin{array}{l}\text { No. of } \mathrm{F}_{1} \mathrm{~s} \text { with } \\
\text { seed cotton } \\
\text { yield/ plant }(\mathrm{g})\end{array}$} & \multirow{2}{*}{$\begin{array}{l}\text { Highest seed } \\
\text { cotton yield/ } \\
\text { plant of } \mathrm{F}_{1} \\
\text { (g) }\end{array}$} & \multirow{2}{*}{$\begin{array}{c}\text { Highest seed } \\
\text { cotton yield/ } \\
\text { plant of } \\
\text { parent (g) }\end{array}$} & \multirow[t]{2}{*}{$\begin{array}{l}\text { Heterosis for } \\
\text { yield over the } \\
\text { best parent }\end{array}$} \\
\hline Female & Male & & $>100$ & $50-100$ & & & \\
\hline 11 & 16 & 176 & 70 & 106 & 215.9 & 162.6 & -100 to $132 \%$ \\
\hline \multicolumn{3}{|c|}{ GOT\% range } & \multicolumn{3}{|c|}{$\begin{array}{l}\text { No. of crosses more than } 35 \% \\
\text { GOT \% }\end{array}$} & \multicolumn{2}{|c|}{$\begin{array}{c}\text { No. of crosses more than } 40 \% \\
\text { GOT }\end{array}$} \\
\hline \multicolumn{3}{|c|}{29.2 to 39.1} & \multicolumn{3}{|c|}{16} & \multicolumn{2}{|c|}{------------ } \\
\hline
\end{tabular}

Table.3 Evaluation of $\mathrm{F}_{2}$ population of 2 selected crosses attempted during 2011-12 for estimation of GOT\%

\begin{tabular}{|c|c|c|c|c|c|c|}
\hline Sr. No. & $\begin{array}{c}\text { Name of the } \\
\text { cross }\end{array}$ & $\begin{array}{c}\text { No. of } \\
\text { plants }\end{array}$ & $\begin{array}{c}\text { GOT\% } \\
\text { range }\end{array}$ & $\begin{array}{c}\text { Seed cotton } \\
\text { yield/ plant } \\
\text { (g) }\end{array}$ & $\begin{array}{c}\text { No. of plants } \\
\text { more than } \\
\text { 35\% GOT }\end{array}$ & $\begin{array}{c}\text { No. of plants } \\
\text { more than } \\
\text { 40\% GOT }\end{array}$ \\
\hline $\mathbf{1}$ & RS-875xSA-524 & 172 & 30.5 to 44.2 & 10 to 75 & 11 & 13 \\
\hline $\mathbf{2}$ & F-1861xSA-668 & 168 & 29.3 to 45.2 & 10 to 100 & 48 & 24 \\
\hline
\end{tabular}


Table. 4 Top 5 genotypes in replicated evaluation of $19 \mathrm{~F}_{5}$ selections of selected crosses

\begin{tabular}{|l|l|c|c|c|c|c|c|c|}
\hline $\begin{array}{l}\text { Genotype/ } \\
\text { Population }\end{array}$ & $\begin{array}{c}\text { Seed } \\
\text { Cotton } \\
\text { Yield } \\
\text { (kg/ha) }\end{array}$ & $\begin{array}{c}\text { Lint } \\
\text { yield } \\
\text { (kg/ha) }\end{array}$ & $\begin{array}{c}\text { Ginni } \\
\text { ng out } \\
\text { turn } \\
\text { per } \\
\text { cent }\end{array}$ & $\begin{array}{c}\text { Boll } \\
\text { weight } \\
\text { (g) }\end{array}$ & $\begin{array}{c}\text { Boll } \\
\text { No. } \\
\text { /plant }\end{array}$ & $\begin{array}{c}\text { Plant } \\
\text { height } \\
\text { (cm) }\end{array}$ & $\begin{array}{c}\text { No. } \\
\text { of } \\
\text { Mon }\end{array}$ & $\begin{array}{c}\text { No. of } \\
\text { Sympods }\end{array}$ \\
opod \\
\hline RS875xSA524 P12 & 2304.52 & 935.60 & 40.60 & 3.02 & 23.90 & 115.00 & 0.33 & 13.93 \\
\hline F1861xSA668 P15 & 2202.85 & 848.00 & 38.50 & 2.65 & 22.20 & 125.00 & 0.57 & 13.38 \\
\hline RS875xSA524 P4 & 2198.01 & 857.22 & 39.00 & 2.85 & 20.37 & 112.00 & 0.80 & 13.13 \\
\hline F1861xSA668 P57 & 1931.73 & 772.4 & 40.00 & 2.83 & 22.90 & 144.20 & 1.57 & 11.73 \\
\hline F1861xSA668 P6 & 1849.42 & $730 . .5$ & 39.50 & 2.58 & 27.90 & 148.17 & 1.13 & 16.80 \\
\hline H 1226 (Check) & 1717.37 & 59249 & 34.50 & 2.80 & 19.10 & 136.33 & 1.20 & 12.33 \\
\hline F1861 (Check) & 1751.09 & 593.40 & 34.00 & 2.90 & 17.67 & 133.50 & 1.17 & 12.00 \\
\hline CD & 292.21 & 80.69 & 1.01 & 0.25 & 3.93 & 19.43 & 0.64 & 2.13 \\
\hline CV (5\%) & 14.63 & 29.54 & 5.95 & 5.38 & 11.07 & 9.61 & 12.28 & 10.15 \\
\hline Overall average & 1,441 & 548.72 & 38.25 & 2.93 & 24.13 & 110.42 & 0.67 & 15.91 \\
\hline Over all range & 897.70 & 364.4 & 32.73 & 2.57 & 18.5 & 85.23 & 0.0 & 11.73 \\
\hline & to & to & to & to & to & to & to \\
\hline & 2304.52 & 935.6 & 40.6 & 3.63 & 29.23 & 136.33 & 1.6 & 18.73 \\
\hline
\end{tabular}

Table.5 Fibre properties of Top 5 genotypes in evaluation of 19 F5 selections of selected crosses

\begin{tabular}{|l|c|c|c|c|}
\hline Genotype/Population & $\begin{array}{c}\text { Span } \\
\text { length } \\
(\mathbf{m m})\end{array}$ & $\begin{array}{c}\text { Uniformity } \\
\text { ratio }\end{array}$ & $\begin{array}{c}\text { Fibre } \\
\text { strength(g/tex) }\end{array}$ & Micronare value \\
\hline RS875xSA524 P12 & 26.8 & 81 & 25.2 & 4.5 \\
\hline F1861xSA668 P15 & 26.9 & 82 & 26.1 & 4.7 \\
\hline RS875xSA524 P4 & 26.7 & 82 & 25.1 & 4.3 \\
\hline F1861xSA668 P57 & 27.3 & 82 & 26.4 & 4.4 \\
\hline F1861xSA668 P6 & 26.8 & 82 & 26.5 & 4.7 \\
\hline H 1226 (Check) & 27.7 & 82 & 25.8 & 4.5 \\
\hline F1861 (Check) & 27.9 & 82 & 26.6 & 4.4 \\
\hline CD & 0.40 & - & 0.34 & 0.16 \\
\hline CV & 3.51 & - & 3.10 & 7.73 \\
\hline Average & 26.59 & 81.86 & 25.54 & 4.78 \\
\hline Range & 24.4 to27.9 & 81 to 82 & 24.1 to26.6 & 4.2 to 5.5 \\
\hline
\end{tabular}


Table.6 Insect pest and CLCuD data of top 5 genotypes in replicated evaluation of $19 \mathrm{~F}_{5}$ progenies of selected crosses

\begin{tabular}{|c|c|c|c|c|c|}
\hline \multirow[t]{2}{*}{ Entry } & \multirow[t]{2}{*}{ Jassid Grade } & \multicolumn{3}{|c|}{ Sucking Pests /3 Leaves } & \multirow{2}{*}{$\begin{array}{l}\quad \text { PDI } \\
\text { (Per cent } \\
\text { Disease Index) } \\
\text { CLUCD }\end{array}$} \\
\hline & & $\begin{array}{c}\text { Leaf } \\
\text { hopper / } \\
\text { 3leaf }\end{array}$ & $\begin{array}{l}\text { White } \\
\text { Fly / } \\
\text { 3leaf }\end{array}$ & Thrips & \\
\hline F1861xSA668 P15 & 1 & 1.30 & 9.53 & 2.90 & 23.89 \\
\hline RS875xSA524 P12 & 1 & 0.80 & 9.47 & 3.03 & 22.22 \\
\hline RS875xSA524 P4 & 1 & 9.40 & 10.2 & 2.70 & 21.11 \\
\hline F1861xSA668 P57 & 1 & 1.23 & 9.93 & 3.53 & 30.00 \\
\hline RS875xSA524 P15 & 1 & 1.17 & 10.53 & 2.60 & 23.33 \\
\hline H 1226 (Check) & 1 & 1.57 & 13.87 & 2.73 & 20.56 \\
\hline F1861 (Check) & 1 & 1.57 & 12.33 & 3.57 & 22.22 \\
\hline Average & 1 & 2.43 & 10.84 & 3.0 & 23.33 \\
\hline Range & 1 to 1 & $\begin{array}{c}0.8 \text { to } \\
9.40\end{array}$ & $\begin{array}{c}9.47 \text { to } \\
13.87\end{array}$ & $\begin{array}{c}2.6 \\
\text { to3.57 }\end{array}$ & 20.56 to 30.0 \\
\hline
\end{tabular}

This was due to significantly higher ginning out turn percent of 19 advance generation populations of the two crosses in comparison to both the check varieties(as lint yield is the product of seed cotton yield and ginning out turn per cent). Significantly higher ginning out turn per cent (38.5 to $40.60 \pm 1.01$ ) was obtained for all the top five entries which was significantly higher than both the check varieties $\mathrm{H}-1226 \quad 34.5 \quad \pm 1.01$ and $\quad \mathrm{F}-1861$ $34.0 \pm 1.01$. Boll weight (g) and boll number/plant were at par with both the checks in top five advance generation populations. RS875xSA524 P12 $115 \pm 1.01 \mathrm{~cm}$ and RS875xSA524 P4 $112.0 \pm 1.01 \mathrm{~cm}$ were dwarf and are suitable for mechanical picking in comparison to both the checks $(136.33 \pm 1.01 \mathrm{~cm}$ and $133.50 \pm 1.01 \mathrm{~cm})$. Number of monopodia branches /plant among the top five high yielding advance generation populations $\quad$ RS875xSA524 P12 F1861xSA668 P15 and RS875xSA524 P4 was less than unity indicating these populations were suitable for mechanical picking. Results are given in Table 4. Top five advance generation populations RS875xSA524 P12, F1861xSA668 P15,
RS875xSA524 P4, F1861xSA668 P57 and F1861xSA668 P6 had fibre properties comparable with the both the checks (Table 5). F1861x SA668 P15, RS875xSA524 P12 and RS875xSA524 P4 had PDI (Per cent disease index) for leaf curl disease CLCuD was 23.89, 22.22 and 21.11 for three populations, respectively, which was equivalent to the highest yielder local check F1861(22.22). Jassid grade injury was recorded as one in these high GOT\% populations as for both the checks (Table 6).

Observance of significant differences among 19 advance generations and two check varieties for all the eight traits viz., seed cotton yield $\mathrm{kg} /$ hectare, lint yield $\mathrm{kg} /$ hectare number of bolls per/plant, boll weight (g), number of monopodia branches/plant, number of sympodia/plant, plant height $(\mathrm{cm})$ including ginning out turn percent indicated that the breeding material possessed sufficient genotypic variability and suggested possibility of selection from them. Delinking of negatively associated desirable (high yield) and undesirable (poor fibre quality) traits had been a breeding challenge in cotton. Joshi and 
his students could address this problem by indigenous breeding/selection strategies. Cotton varieties known as JK series ( $\mathrm{J}$ stands for Joshi and $\mathrm{K}$ for Kadappa, student of Joshi and well-known cotton breeder in Karnataka) combining high ginning outturn and high fibre strength and fineness in high-yield backgrounds are the outcome of this effort. It was his belief that yield stagnation at low levels for long in cotton could be breached by exploitation of hybrid vigour (Siddiq, 2010).

Over all evaluation of the experimental material indicated that the two check varieties had lint yield $\mathrm{kg} /$ hectare $592.49 \pm 80.69$ and $593.40 \pm 80.69$ and the average lint yield $\mathrm{kg} /$ hectare was $548.72 \pm 80.69$ which was statically at par with both of the check varieties indicating that though the seed cotton yield of 19 advance generation populations of the two crosses had significantly lesser seed cotton yield $\mathrm{kg} /$ hectare in comparison to the check variety F-1861. This was due to significantly higher ginning out turn percent of 19 advance generation populations of the two crosses in comparison to both the check varieties (as lint yield is the product of seed cotton yield and ginning out turn per cent). Solanki et al., (2014) found that number of sympodia per plant, number of bolls per plant, boll weight and lint yield per plant were the main contributors towards increase in heterotic effects for seed cotton yield per plant.

Overall average plant height $(\mathrm{cm})$ of 19 advance generation populations of the two crosses and two checks was $110.42 \pm 19.43$ and that of the two check varieties was $136.33 \pm 19.43$ and 133.0 \pm 19.43 , this suggested that advance generation material had dwarfed populations suitable for mechanical picking. Number of monopodia branches/plant possessed by the check variety H-1226 and F-1861 were 1.2 \pm 0.64 Number of monopodia branches/plant possessed by the check variety $\mathrm{H}-1226$ and $\mathrm{F}-1861$ were $1.2 \pm 0.64$ and1.1.17 \pm 0.64 respectively, whereas overall average was $0.67 \pm 0.64$ This observation suggested that the breeding material evaluated possessed populations which had less than average 0.67 number of monopodia branches/plant and were suitable for mechanical picking (Gwathmey and Clement, 2010).

Out of top five three advance generation populations RS875xSA524 P12, F1861xSA668 P15, RS875xSA524 P4, had significantly higher seed cotton yield and lint yield $\mathrm{kg} /$ hectare in comparison to both the check varieties H1226 (1717.37 \pm 292.3 and $592.49 \pm 80.69$ and F18611751.09 \pm 292.3 and

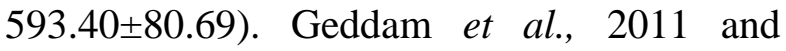
Chaudhary et al., (2015) also found yield increase in $\mathrm{F}_{2}$ generation is quite satisfactory. Their encouraging results suggest there is sufficient scope to use $\mathrm{F}_{2}$ hybrids and advance generation material with increased yield on commercial scale. High heterosis was found to be highly heterotic for seed cotton yield, number of sympodia, number of bolls per plant and ginning out turn (Zia et al., 2001). Less than one monopod and lesser plant height in comparison to both the check varieties suggest suitability of high yielder and high ginning out turn top five advance generation material. The present study reveals good scope for the isolation of pure lines from the progenies of heterotic $F_{1} s$ for high seed cotton yield and high ginning out turn. More so, these populations have comparable less disease and insect pest tolerance and fibre properties

\section{References}

Ansari, A.H., Malik, M.A., Qayyum, S.M. and Ansari, N.N. 1989. Phenotypic correlation and regression analysis in cotton (Gossypium hirsutum L.). B Res J Agric Sci Rev. 27: 89-93. 
Geddam, S.B., Khadi, B.M., Mogalu, S., Patil, R.S., Katageri, I.S., Nadafand, H.L. and Patil, B.C. 2011. Study of heterosis in genetic male sterility based diploid cotton hybrids for yield, yield component and fibre quality characters. Karnataka J Agril Sci., 24: 118-124

Gwathmey, C.O. and J.D. Clement. 2010. Alteration of cotton source sink relations with plant population density and mepiquat chloride. Field Crops Research. 16: 101-107

Hanif, C.H., Abid, M.A., Rehman, S., Ashraf, J., Malik, W., Khan, F.Z., Bilal, M., Qanmber, G. and Ahmad, F. 2015. Exploitation of Heterosis in F1 and F2 generations of cotton $(G$. hirsutum L.) B Res J Agric Sci Rev. 4: 234-238

Iqbal, M., Chang, M.A., Iqbal, M.Z., Hassan, M., Karim, A. and Ahmad, S. 2003. Breeding Behaviour effects for yield, its components and fibre quality traits in intraspecific crosses of cotton (G.hirsutum). Online J Bio Sci. 3: 451459

Islam, Z., Sadaqat, H.A. and Khan, F.A. 2001. Combining ability of some hirsute cotton types for economic traits. Int $\mathrm{J}$ Agric Biol. 3: 411-412

Monga, D. 2014. Cotton leaf curl virus diseases. Central Institute for Cotton Research, Regional Station, Sirsa 125055, India.

Panhwar, S.A., Baloch, M.J., Jatoi, W.A., Veesar, N.F. and Majeedano, M.S. 2008. Combining ability estimates from line $\mathrm{x}$ tester mating design mating design in upland cotton. Proc Pakistan Acad Sci 45: 69-74
Panse, V.C. and Sukhatme, P.V. 1978. Statistical methods for Agricultural workers. III Rev. Ed. ICAR, New Delhi.

Siddiq, E.A. 2010. Personal News: Current science, 99 (12), 25 December, 1847-48 Center for DNA Fingerprinting and Diagnostics (CDFD). Bldg. 7. Gruhakalpa, 5-4-399/B, Nampally, Hyderabad 500 001, India.

Singh, R.K. and Chaudhary, B.D. 1985. Biometrical methods in Quantitative Genetic Analysis. Kalyani Publishers, New Delhi.

Solanki, H.V., Mehta, D.R., Rathod, V.B. and Valu, M.G. 2014. Heterosis for seed cotton yield and its contributing characters in cotton (Gossypium hirsutum L.). Electronic J Plant Breed. 5: $124-130$

Wu, J., McCarty, J.C., Jenkins, J.N. and Meredith, W.R. 2010. Breeding potential of introgressions into upland cotton: genetic effects and heterosis. Plant Breeding 129: 526-532 https://doi.org/10.1111/j.1439-0523.20 09.01715.X

Yuan, Y.L., Zhang, T.Z., Guo, W.Z., Pan, J.J. and Kohel, R.J. 2002. Heterosis andgene action of boll weight and lint percentage in high quality fiber property varieties in upland cotton. Acta Agron Sinica. 28: 196-202.

Yuan, Y.L., Zhang, T.Z., Jing, S.R., Pan, J.J., Xing, C.Z., Guo, L.P., and Tang, C.M. 2001. Studies of the inheritance of seed qualities and the exploitation of F2 heterosis in low gossypol strains in upland cotton. Acta Genet Sin. 28: 471481

\section{How to cite this article:}

Ahuja, S.L., D. Monga, Rishi Kumar and Sain, S.K. 2018. Evaluation of Advance Generation Populations of Cotton (Gossypium hirsutum L.) for High Ginning Out Turn Percent and Yield. Int.J.Curr.Microbiol.App.Sci. 7(09): 3097-3105. doi: https://doi.org/10.20546/ijcmas.2018.709.386 